\title{
Evaluation of Crystalline Silicotitanate and Self-Assembled Monolayers on Mesoporous Support for Cesium and Mercury Removal from DWPF Recycle
}

by

L. N. Oji

Westinghouse Savannah River Company

Savannah River Site

Aiken, South Carolina 29808

This paper was prepared in connection with work done under the above contract number with the U.S.

Department of Energy. By acceptance of this paper, the publisher and/or recipient acknowledges the U.S.

Government's right to retain a nonexclusive, royalty-free license in and to any copyright covering this paper, along with the right to reproduce and to authorize others to reproduce all or part of the copyrighted paper. 
EVALUATION OF CRYSTALLINE SILICOTITANATE AND SELFASSEMBLED MONOLAYERS ON MESOPOROUS SUPPORT FOR CESIUM AND MERCURY REMOVAL FROM DWPF RECYCLE.

Key Words: Radioactive cesium,

Heavy metals, Wastewater

Retention Time: Permanent

Author: Lawrence N. Oji 773-43A

Report Date: September 22, 1999

Westinghouse Savannah River Company Savannah River Site Aiken. SC 29808

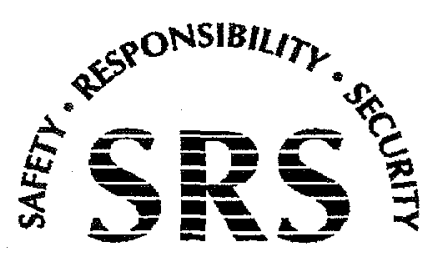




\section{DISCLAIMER}

This report was prepared as an account of work sponsored by an agency of the United States Government. Neither the United States Government nor any agency thereof, nor any of their employees, makes any warranty, express or implied, or assumes any legal liability or responsibility for the accuracy, completeness, or usefulness of any information, apparatus, product, or process disclosed, or represents that its use would not infringe privately owned rights. Reference herein to any specific commercial product, process, or service by trade name, trademark, manufacturer, or otherwise does not necessarily constitute or imply its endorsement, recommendation, or favoring by the United States Government or any agency thereof. The views and opinions of authors expressed herein do not necessarily state or reflect those of the United States Government or any agency thereof.

This report has been reproduced directly from the best available copy.

Available to DOE and DOE contractors from the Office of Scientific and Technical Information, P.O. Box 62, Oak Ridge, TN 37831; prices available from (615) 576-8401.

Available to the public from the National Technical Information Service, U.S. Department of Commerce, 5285 Port Royal Road, Springfield, VA 22161. 
EVALUATION OF CRYSTALLINE SILICOTITANATE AND SELFASSEMBLED MONOLAYERS ON MESOPOROUS SUPPORT FOR CESIUM AND MERCURY REMOVAL FROM DWPF RECYCLE.

Key Words: Radioactive cesium,

Heavy metals, Wastewater

Retention Time: Permanent

Author: Lawrence N. Oji 773-43A

Report Date: September 22, 1999

Westinghouse Savannah River Company Savannah River Site

Aiken. SC 29808

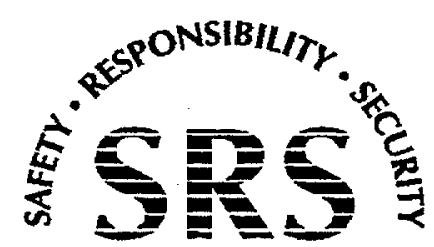


WSRC-RP-99-00331 Rev. 0

September 22, 1999

REVIEWS AND APPROVALS

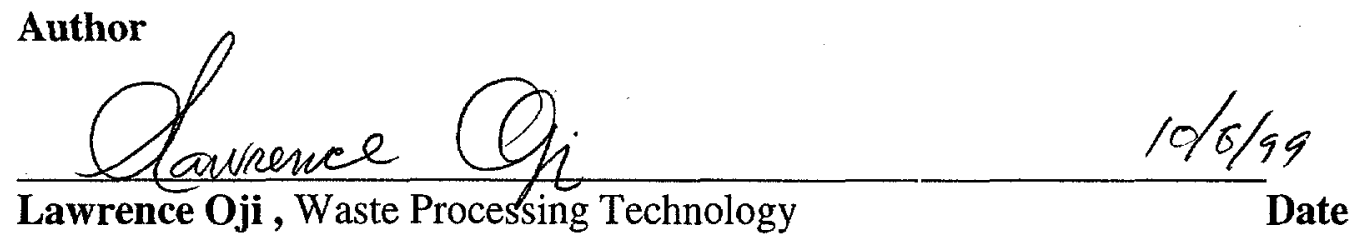

Design Check
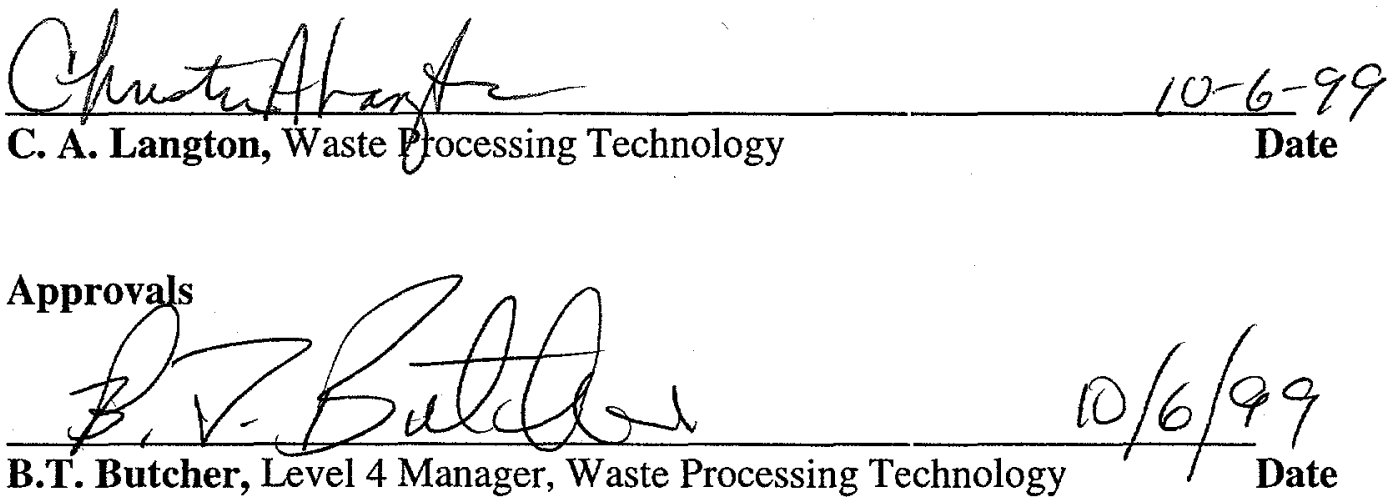

M. C. Thompson 10/2/99

M. C. Thompson, chemical Hydrogen Technology Section

Date

ii 


\section{TABLE OF CONTENTS}

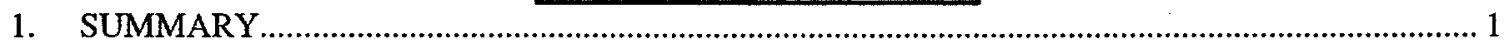

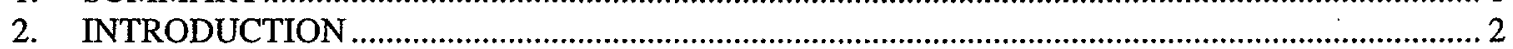

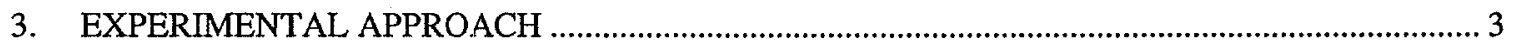

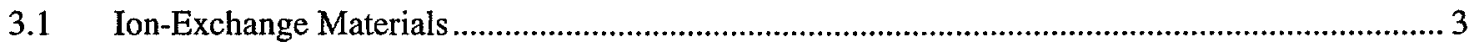

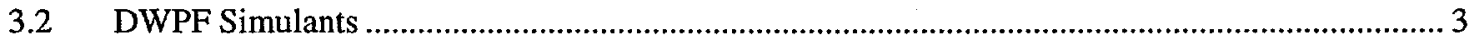

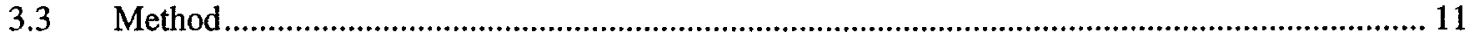

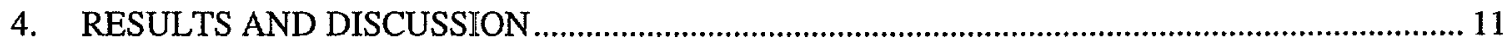

4.1 Cesium Uptake with CST in an Inorganic DWPF Simulant............................................. 11

4.2 Cesium Uptake with CST in Organic and Inorganic DWPF Simulants................................... 12

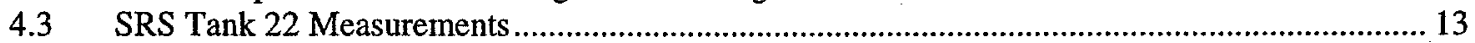

4.4 Variation of Batch Distribution Coefficient With Cesium Concentration ................................ 13

4.5 Variation of Batch Distribution Coefficient With Ionic Strength. ......................................... 15

4.6 Experiments With Cesium-137 Spiked Tank-22 Simulant............................................... 16

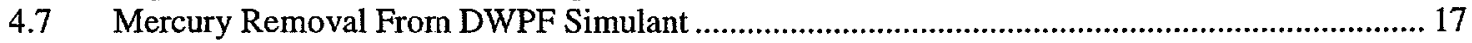

4.8 Mercury Removal From Tank 22 Sample With GT-73.Resin ............................................ 18

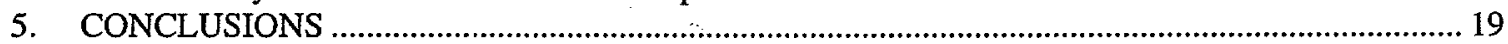

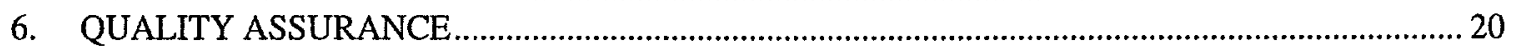

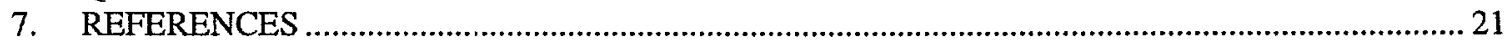

\section{LIST OF FIGURES}

Figure 1. Variation of $\mathrm{K}_{\mathrm{d}}$ With Initial Cesium Concentration. .................................................................. 14

Figure 2. Linear Response of $\mathrm{K}_{\mathbf{d}}$ with Cesium Decontamination Factor................................................ 15

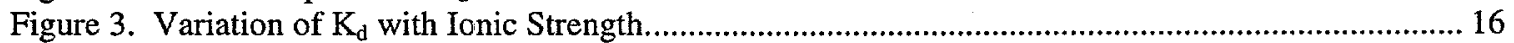

Figure 4. Estimated $\mathrm{K}_{\mathrm{d}}$ Variation Profile with $\mathrm{pH}$ for Mercury Removal with SAMMS.......................... 19

Figure 5 Variation of Kd with $\mathrm{pH}$ for Mercury Removal with Duolite GT-73 .......................................... 19

\section{LIST OF TABLES}

Table 1 Summary of Test Cases.

Table 2. Simulant Inorganic Composition Used for Cesium Uptake with CST. ............................................ 4

Table 3. DWPF Simulants: High Inorganic/Sodium Compositions. ......................................................... 6

Table 4. DWPF Simulants: High Organic/ Sodium Compositions................................................................ 7

Table 5. DWPF Simulants: Average Organic Compositions............................................................... 8

Table 6. DWPF Simulants: Average Inorganic Compositions .............................................................. 9

Table 7. Organic and Inorganic Components for Tank $22 \mathrm{H}$ Simulant Solution....................................... 10

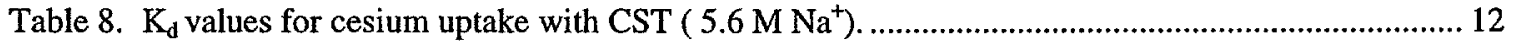

Table 9. $\mathrm{K}_{\mathrm{d}}$ Variation with Initial Cesium Concentration....................................................................... 13

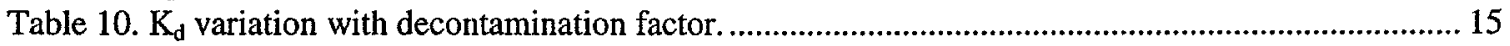

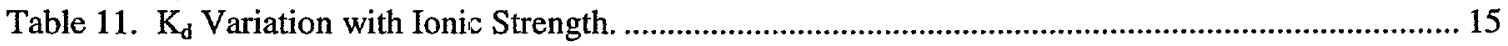

Table 12. Data Summary for Tank-22 Simulants Spiked with Cesium-137 .............................................. 17

Table 13. Kd Values for SAMMS and Duolite GT-73 Resin for Mercury Removal ................................ 18

Table 14. $\mathrm{K}_{d}$ Values for SAMMS and Duolite GT-73 Resin for Mercury Removal from Tank-22 Simulant. 

AND MERCURY REMOVAL FROM DWPF RECYCLE (U).

\section{SUMMARY}

The affinities for cesium and mercury ions contained in DWPF recycle simulants and Tank-22H waste have been evaluated using Crystalline Silicotitanate (CST) and SelfAssembled Monolayers on Mesoporous Support (SAMMS) ion-exchange materials, respectively. Results of the performance evaluations of CST on the uptake of cesium with simulants and actual DWPF recycle samples (Tank 22H) indicate that, in practice, this inorganic ion-exchange material can be used to remove radioactive cesium from the DWPF recycle. SAMMS naterial showed little or no affinity for mercury from highly alkaline DWPF waste. However, at near neutral conditions (DWPF simulant solution $\mathrm{pH}$ adjusted to 7), SAMMS was found to have a significant affinity for mercury. Conventional Duolite ${ }^{\otimes}$ GT-73 ion exchange material showed an increase in affinity for mercury with increase in DWPF recycle simulant pH. Duolite ${ }^{\circledR}$ GT-73 also had a high batch distribution coefficient for mercury uptake from actual Tank $22 \mathrm{H}$ waste. 


\section{INTRODUCTION}

High-Level Waste (HLW) is pretreated and vitrified in the Defense Waste Processing Facility (DWPF) at the Savannah River Site (SRS). The DWPF process generates a large volume of aqueous waste known as DWPF recycle, which is returned to the HLW tank system for storage and evaporation.

The DWPF recycle stream is an aqueous waste stream, which is returned to the Tank Farms through tank $43 \mathrm{H}$ and the $2 \mathrm{H}$-evaporator system. The stream is comprised of numerous streams from within DWPF. Waste from the Slurry Mix Evaporator Condensate Tank (SMECT), Off-Gas Condensate Tark (OGCT), and smaller amounts of dilution waters and DWPF laboratory waste are sent to the Recycle Collection Tank (RCT). Batches of this waste are collected in the RCT and then caustic adjusted (inhibition process for corrosion control) before transfer to tank $43 \mathrm{H}$. Waste collected in the RCT may alternate between SMECT and OGCT, that is, one batch may be primarily SMECT while the next batch is OGCT waste. The SMECT waste stream is the main source of organic compounds in the RCT, although some small quantities of organics are also introduced from the DWPF laboratories.

Cesium-137, strontium-90, mercury and traces of transuranic elements are the primary constituents of concern in the DWPF recycle waste. The proposed path is to use ionexchange technology to decontaminate the DWPF recycle waste stream and send the decontaminated aqueous stream through the general purpose evaporator to the Effluent Treatment Facility (ETF). This approach would eliminate the current practice of sending the DWPF recycle to the HLW tank farm relieving HLW of storage capacity problems. The continuous operation of DWPF would be erisured and the long-term storage problems for the Tank Farms would be alleviated.

The Efficient Separation Program (ESP) funded this investigation with the following principal goals:

- Qualify Crystalline Silicotitanate (CST) ion-exchange material for the removal of radioactive cesium and, possibly, transuranic elements from the DWPF recycle waste stream,

- Evaluate Sodium Titanate (ST) affinity for the uptake of strontium-90 from the DWPF waste stream and the effect of ST particle size on the cross-flow filtration process (currently not part of objective because of limited funding resources), and

- Evaluate and compare the affinity for mercury in the DWPF recycle waste by other ion-exchange materials like the Self-Assembled Monolayers on Mesoporous Support (SAMMS) material and standard Duolite GT-73 resin. 


\section{EXPERIMENTAL APPROACH}

The purpose of this study was to examine the feasibility of using CST for cesium removal from DWPF recycle, and to compare two ion-exchange materials, Duolite GT-73 and SAMMS, for chemisorption of mercury. Important variables in assessing the viability of these materials under conditions found at DWPF are $\mathrm{pH}$, initial cesium concentration, organic concentration, and sodium concentration. Cesium and mercury uptake behavior under the expected range of conditions was conducted for these materials using various simulants for the DWPF recycle stream.

\subsection{Ion-Exchange Materials}

An engineered granular form of CST ion exchange material from UOP*, known as Ionsive $^{\circledR}$ IE-911, (lot \# 999096810002), was used in this study (1). Dr. Feng of Pacific Northwest National Laboratory (PNNL) provided the SAMMS material and the Duolite ${ }^{\circledR}$ GT-73, sodium form, was obtained locally on site. Sodium Titanate slurry was obtained from Allied Signal (Allied Signal Research and Technology, 50 East Algonquin Road, Des Plaines, IL 60017-5016).

\subsection{DWPF Simulants}

DWPF simulants were selected to represent the expected range of constituents and conditions based on consultation with HLW Engineering. As the project proceeded focus of the work shifted to Tank 22 which is currently the intermediate storage destination for DWPF recycle and other Tank Farm dilute waste streams. In addition, a funding shortfall resulted in a delay in analyzing samples from initial CST runs. The analytical results from these runs are suspect. As a result, additional tests were run using a Tank 22 simulant. Table 1 is a summary of the test cases for this study.

The uptake of cesium-137 surrogate with CST was first evaluated with a simulant from earlier CST testing (3) to provide a baseline for the method used in this experiment. This inorganic simulant composition, shown in Table 2, is representative of typical HLW salt waste composition.

Caustic adjustments in the RCT, as described earlier, put sodium concentrations in the RCT in the range of 0.5 to 5.4 molar. Based principally on these sodium concentrations, three types of basic DWPF test solutions (simulants) were used in this study:

\footnotetext{
" UOP, 307 Fellowship Road, Suite 207, Mount Laurel, NJ (856-727-9400)
} 
Table 1 Summary of Test Cases.

\begin{tabular}{|c|c|c|c|c|}
\hline $\begin{array}{c}\text { Sorbent Tested } / \\
\text { Contam. Removed }\end{array}$ & $\begin{array}{l}\text { Simulant } \\
\text { Evaluated }\end{array}$ & $\begin{array}{c}\text { Solution } \\
\text { Composition }\end{array}$ & Results & $\begin{array}{l}\text { Experimental } \\
\text { Variable }\end{array}$ \\
\hline CST / Cs133 & $\begin{array}{l}\text { Baseline salt } \\
\text { simulant } \\
\text { compostion }\end{array}$ & Table 2 & Table 8 & $\begin{array}{l}\text { None. Compari- } \\
\text { son with earlier } \\
\text { results (Ref. 3) }\end{array}$ \\
\hline CST/Cs133 & $\begin{array}{l}\text { High sodium/ } \\
\text { organic/inorganic } \\
\text { DWPF recycle }\end{array}$ & Tables $3 \& 4$ & $\begin{array}{l}\text { None. Funding } \\
\text { delay. }\end{array}$ & $\mathrm{pH}$ \\
\hline CST / Cs133 & $\begin{array}{l}\text { Avg. sodium/ } \\
\text { organic/inorganic } \\
\text { DWPF recycle }\end{array}$ & Tables $5 \& 6$ & $\begin{array}{l}\text { None. Funding } \\
\text { delay. }\end{array}$ & $\overline{\mathrm{pH}}$ \\
\hline CST / Cs133 & $\begin{array}{l}\text { TNX SMECT } \\
\text { sample }\end{array}$ & $\begin{array}{l}\text { Not available } \\
\text { except for Cs }\end{array}$ & $\begin{array}{l}\text { None. Funding } \\
\text { delay. }\end{array}$ & $\mathrm{pH}$ \\
\hline CST / Cs 133 & $\begin{array}{l}\text { Tank } 22 \text { simulant } \\
\text { (low sodium) }\end{array}$ & Table 7 & $\begin{array}{l}\text { Tables } 9 \& 10 \\
\text { Figures } 1 \& 2\end{array}$ & $\begin{array}{l}\text { Initial cesium (Cs- } \\
\text { 133) concentration }\end{array}$ \\
\hline CST / Cs133 & $\begin{array}{l}\text { Tank } 22 \text { simulant } \\
\text { (low sodium) }\end{array}$ & Table 7 & $\begin{array}{l}\text { Table } 11 \\
\text { Figure } 3\end{array}$ & $\begin{array}{l}\text { Sodium } \\
\text { concentration }\end{array}$ \\
\hline CST / Cs137 & $\begin{array}{l}\text { Tank } 22 \text { simulant } \\
\text { (low sodium) }\end{array}$ & Table 7 & Table 12 & $\begin{array}{l}\text { Radioactive } \\
\text { cesium }\end{array}$ \\
\hline $\begin{array}{l}\text { SAMMS, GT-73 \& } \\
\text { Sulfur / Mercury }\end{array}$ & $\begin{array}{l}\text { High sodium/ } \\
\text { organic/inorganic } \\
\text { DWPF recycle }\end{array}$ & Tables $3 \& 4$ & Table 13 & Sorbent tested \\
\hline $\begin{array}{l}\text { SAMMS \& GT-73 } \\
\text { / Mercury }\end{array}$ & $\begin{array}{l}\text { Tank } 22 \text { simulant } \\
\text { (low sodium) }\end{array}$ & Table 6 & $\begin{array}{l}\text { Table } 14 \\
\text { Figures } 4 \text { \& } 5\end{array}$ & $\mathrm{pH}$ \\
\hline
\end{tabular}

Table 2. Simulant Inorganic Composition Used for Cesium Uptake with CST.

\begin{tabular}{|c|c|c|}
\hline Precursor/target ion & Target concentration (M) & Precursor per Liter (g/L) \\
\hline $\mathrm{Na}_{2} \mathrm{SO}_{4} / \mathrm{SO}_{4}{ }^{\circ}$ & 0.17 & 24.10 \\
\hline $\mathrm{NaNO}_{2} / \mathrm{NO}_{2}^{-}$ & 0.71 & 48.70 \\
\hline $\mathrm{NaNO}_{3} / \mathrm{NO}_{3}{ }^{-}$ & 1.20 & 102.00 \\
\hline $\mathrm{KNO}_{3} / \mathrm{K}^{+}$ & 0.015 & 1.52 \\
\hline $\mathrm{CsNO}_{3} /(\mathrm{Cs}-133)$ & $2.4 \mathrm{E}-4$ & 0.047 \\
\hline $\mathrm{Na}_{2} \mathrm{CO}_{3} \cdot \mathrm{H}_{2} \mathrm{O} / \mathrm{CO}_{3}{ }^{-}$ & 0.2 & 24.8 \\
\hline $\mathrm{NaOH}^{-} / \mathrm{OH}^{-}$ & 2.9 & 116.0 \\
\hline $\mathrm{Al}\left(\mathrm{NO}_{3}\right)_{3} .9 \mathrm{H}_{2} \mathrm{O} / \mathrm{Al}^{+3}$ & 0.38 & 142.5 \\
\hline
\end{tabular}


A. High inorganic/organic and high sodium (5.4 $\left.\mathrm{M} \mathrm{Na}^{+}\right)$simulant (Tables 3 and 4).

B. Average inorganic/organic and average sodium $\left(1.4 \mathrm{M} \mathrm{Na}^{+}\right.$) simulant (See Tables 5 and 6).

C. Average inorganic/organic and low sodium $\left(0.5 \mathrm{M} \mathrm{Na}^{+}\right)$simulants (Table 7).

The last simulant type (Type C) was designed to reflect waste from Tank-22 which is currently the intermediate storage destination for DWPF recycle and other Tank Farm dilute waste streams. A range of cesium concentrations were tested $(6-60 \mathrm{mg} / \mathrm{L} \mathrm{Cs}-133)$ with Tank 22 simulant to assess variation of batch distribution coefficient with initial cesium concentration. Experiments were also conducted with cesium-137 spiked Tank 22 simulant $(20 \mu \mathrm{g} / \mathrm{L}$ Cs-137) which is more representative of actual Tank 22 cesium concentration. Finally, ranges of sodium concentrations were tested for Tank 22 simulant to assess the impact of ionic strength on cesium uptake.

In the comparative evaluations of SAMMS and Duolite ${ }^{\circledR}$ GT-73 resin for mercury uptake from DWPF recycle, simulant Types $A$ and $C$ spiked with mercury solutions were used. Some mercury solutions were prepared directly from mercuric chloride. Russ Eibling of SRTC provided other mercuric test solutions from old TNX process SMECT test runs already containing organic compounds. Cesium-133, as cesium nitrate precursor, was used as the surrogate for radioactive cesium-137. 
Table 3. DWPF Simulants: High Inorganic/Sodium Compositions. (Inorganic components for simulant type A)

\begin{tabular}{|c|c|c|}
\hline \multirow[t]{2}{*}{ Chemical (Inorganic) } & \multicolumn{2}{|c|}{ RCT Simulant- High } \\
\hline & $\mathrm{g} / \mathrm{L}$ & $\mathrm{M} / \mathrm{L}$ \\
\hline $\mathrm{KOH}$ & 2.000 & $0.356\left[\mathrm{~K}^{+}\right]$ \\
\hline \multirow[t]{2}{*}{$\mathrm{NH}_{3}$} & 0.600 & $0.008\left[\mathrm{NH}_{3}\right]$ \\
\hline & $\mathrm{g} / \mathrm{L}$ & {$\left[\mathrm{Na}^{+}\right], \mathrm{M} / \mathrm{C}$} \\
\hline $\mathrm{Na}_{2} \mathrm{~B}_{4} \mathrm{O} 7$ & 0.150 & $1.49 \mathrm{E}-3$ \\
\hline $\mathrm{NaCOOH}$ & 0.870 & 0.013 \\
\hline $\mathrm{Na}_{2} \mathrm{C}_{2} \mathrm{O} 4$ & 60.00 & 0.896 \\
\hline $\mathrm{NaCl}$ & 0.008 & $1.368 \mathrm{E}-4$ \\
\hline $\mathrm{NaF}$ & 0.017 & $4.048 \mathrm{E}-4$ \\
\hline $\mathrm{NaNO}_{2}$ & 37.00 & 0.536 \\
\hline $\mathrm{NaNO}_{3}$ & 120.00 & 1.412 \\
\hline $\mathrm{NaOH}$ & 100.00 & 2.500 \\
\hline $\mathrm{Na}_{2} \mathrm{SO}_{4}$ & 0.080 & 0.014 \\
\hline TOTAL $\left[\mathrm{Na}^{+}\right]$ & & $5.373 \mathrm{M} / \mathrm{L}$ \\
\hline \multirow[t]{2}{*}{$\begin{array}{c}\mathrm{CsNO}_{3} \\
\text { (Cs-133 precursor) } \\
\end{array}$} & $0.004 \mathrm{~g} / \mathrm{L}$ & $\begin{array}{l}3.55 \mathrm{E}-3 \\
\mathrm{M} / \mathrm{L} \mathrm{Cs}\end{array}$ \\
\hline & $\mathrm{ppm}$ & \\
\hline Phosphate & 2,200 & \\
\hline Fluoride & 880 & \\
\hline Formate & 160 & \\
\hline Chloride & 900 & \\
\hline Cesium & 2.3 & \\
\hline Carbonate & 190 & \\
\hline & & \\
\hline
\end{tabular}


Table 4. DWPF Simulants: High Organic/Sodium Compositions.

(Organic components for simulant Type A)

\begin{tabular}{|c|c|c|}
\hline Organic Compound & $\mathrm{mg} / \mathrm{L}$ & Comments \\
\hline Benzene & 10 & $\begin{array}{l}\text { Not used due to } \\
\text { its properties }\end{array}$ \\
\hline Aniline & 130 & \\
\hline & 1 & \\
\hline Sodium Phenoxide 2- & 620 & \\
\hline Sodium nitophenoxide 4- & 170 & \\
\hline Nitrobenzene & 350 & \\
\hline Sodium dinitrophenoxide $2,4-$ & 1700 & \\
\hline Sodium phenylphenoxide 2- & 4 & \\
\hline Sodium phenylphenoxide 2- & 11 & \\
\hline Sodium phenylphenoxide 4- & 11 & \\
\hline Sodium phenylazophenoxide4- & 25 & \\
\hline Glycerine & 200 & \\
\hline Acetonitrile & 150 & \\
\hline Acetone & 75 & \\
\hline Methylene Chloride & 73 & \\
\hline Hydrogen peroxide & 51 & \\
\hline Surfyol 420 & 50 & \\
\hline Quinone & 10 & \\
\hline Biphenyl & 10 & \\
\hline Terphenyl-0 & 10 & \\
\hline Terphenyl-m & 10 & \\
\hline Terphenyl-p & 10 & \\
\hline Diphenylamine & 10 & \\
\hline Triphenylamine & 10 & \\
\hline Nitrodiphenylamine & 10 & \\
\hline Phenylformamide & 10 & \\
\hline Dihenylformamide & 5 & \\
\hline Carbazole & 10 & \\
\hline 3H-phenoxazin-3-one & 5 & \\
\hline
\end{tabular}


WSRC-RP-99-00331 Rev. 0

September 22, 1999

Page 8 of 21

Table 5. DWPF Simulants: Average Organic Compositions.

(Organic components for simulant Type B)

\begin{tabular}{|c|c|c|}
\hline Organic Compound & $\mathrm{mg} / \mathrm{L}$ & Comments \\
\hline Benzene & 1 & Not used due to its properties \\
\hline Aniline & 30 & \\
\hline Nitrobenzene & 0.2 & \\
\hline Sodium Phenoxide 2- & 90 & As phenol \\
\hline Sodium nitophenoxide 4- & 50 & \\
\hline Sodium nitrosophenoxide 4- & 90 & \\
\hline Sodium dinitrophenoxide 2,4 & 410 & \\
\hline Sodium phenylphenoxide 2 - & $<0.6$ & \\
\hline Sodium phenylphenoxide 2 - & $<1$ & \\
\hline Sodium phenylphenoxide 4- & $<1$ & \\
\hline Sodium phenylazophenoxide4- & 6 & \\
\hline Glycerine & 3.2 & Lab. Chemical in RTC \\
\hline Acetonitrile & 5 & Lab. Chemical in RTC \\
\hline Acetone & 2.5 & Lab. Chemical in RTC \\
\hline Methylene Chloride & 2.4 & \\
\hline Hydrogen peroxide & 0.85 & \\
\hline Surfyol 420 & 25 & \\
\hline Quinone & 1 & \\
\hline Biphenyl & 3 & \\
\hline Terphenyl-0 & 1 & \\
\hline Terphenyl-m & 1 & \\
\hline Terphenyl-p & 1 & \\
\hline Diphenylamine & 3 & nitrophenylamine used \\
\hline Triphenylamine & 1 & nitrophenylamine used \\
\hline Nitrodiphenylamine & $<1$ & nitrophenylamine used \\
\hline Phenylformamide & $<5$ & \\
\hline Dihenylformamide & $\overline{1}$ & \\
\hline Carbazole & $<1$ & \\
\hline 3H-phenoxazin-3-one & 1 & Not available \\
\hline
\end{tabular}


Table 6. DWPF Simulants: Average Inorganic Compositions

(Inorganic components for simulant Type B)

\begin{tabular}{|c|c|c|c|}
\hline \multirow[t]{2}{*}{ Inorganic Compound } & \multicolumn{2}{|c|}{ RCT Simulant- Average } & \multirow[t]{2}{*}{ Comments } \\
\hline & $g / L$ & $\mathrm{M} / \mathrm{L}$ & \\
\hline $\mathrm{KOH}$ & 0.090 & $1.60 \mathrm{E}-3$ & competing ion for $\mathrm{Cs}$ \\
\hline \multirow{2}{*}{$\mathrm{NH}_{3}$} & 0.300 & $0.004\left[\mathrm{NH}_{3}\right]$ & As ammonium nitrate \\
\hline & $\mathrm{g} / \mathrm{L}$ & {$\left[\mathrm{Na}^{+}\right], \mathrm{M} / \mathrm{L}$} & \\
\hline $\mathrm{Na}_{2} \mathrm{~B}_{4} \mathrm{O} 7$ & 0.037 & $3.68 \mathrm{E}-4$ & As sodium chloride \\
\hline $\mathrm{NaCOOH}$ & 0.210 & 0.003 & \\
\hline $\mathrm{Na}_{2} \mathrm{C}_{2} \mathrm{O} 4$ & 1.300 & 0.019 & \\
\hline $\mathrm{NaCl}$ & 0.002 & $3.42 \mathrm{E}-5$ & \\
\hline $\mathrm{NaF}$ & 0.004 & $9.52 \mathrm{E}-5$ & \\
\hline $\mathrm{NaNO}_{2}$ & 6.000 & 0.087 & \\
\hline $\mathrm{NaNO}_{3}$ & 2.600 & 0.306 & \\
\hline $\mathrm{NaOH}$ & 40.000 & 1.000 & \\
\hline $\mathrm{Na}_{2} \mathrm{SO}_{4}$ & 0.020 & 0.003 & \\
\hline TOTAL $\left[\mathrm{Na}^{+}\right]$ & & $1.418 \mathrm{M} / \mathrm{L}$ & \\
\hline \multirow[t]{2}{*}{$\begin{array}{c}\mathrm{CsNO}_{3} \\
\text { (Cs-133 precursor) } \\
\end{array}$} & $\begin{array}{c}0.001 \\
\mathrm{~g} / \mathrm{L}\end{array}$ & $\begin{array}{l}8.875 \mathrm{E}-4 \\
\mathrm{M} / \mathrm{L} \mathrm{Cs}\end{array}$ & \\
\hline & $\mathrm{ppm}$ & & \\
\hline Phosphate & 37 & & Lab. Chemical in RTC \\
\hline Fluoride & 15 & & Lab. Chemical in RTC \\
\hline Formate & 2.7 & & Lab. Chemical in RTC \\
\hline Chloride & 15 & & Lab. Chemical in RTC \\
\hline Cesium & 0.038 & & Lab. Chemical in RTC \\
\hline Carbonate & 3.1 & & Lab. Chemical in RTC \\
\hline
\end{tabular}


Table 7. Organic and Inorganic Components for Tank 22 H Simulant Solution.

(Organic and inorganic components for simulant Type C)

\begin{tabular}{|c|c|}
\hline Inorganic components & Concentration, Moles/L \\
\hline $\mathrm{KOH}$ & $1.783 \mathrm{E}-2$ \\
\hline $\mathrm{NH}_{3}$ as $\mathrm{NH}_{4} \mathrm{NO}_{3}$ & $4.706 \mathrm{E}-4$ \\
\hline $\mathrm{NaCl}$ & $2.222 \mathrm{E}-4$ \\
\hline $\mathrm{NaF}$ & $3.175 \mathrm{E}-5$ \\
\hline $\mathrm{NaNO}_{2}$ & $2.900 \mathrm{E}-5$ \\
\hline $\mathrm{NaNO}_{3}$ & $1.020 \mathrm{E}-2$ \\
\hline $\mathrm{NaOH}$ & 0.333 \\
\hline $\mathrm{Na}_{2} \mathrm{SO}_{4}$ & $4.700 \mathrm{E}-5$ \\
\hline $\mathrm{CsNO}_{3}$ & 0.00024 ( 32 ppm Cs-133) \\
\hline Organic component & Concentration, $\mathrm{mg} / \mathrm{L}$ \\
\hline Sodium oxalate & 433.3 \\
\hline Sodium formate & 70 \\
\hline Aniline & 30,0 \\
\hline Nitrobenzene & 0.2 \\
\hline Sodium phenoxide 2 - & (as phenol) \\
\hline Sodium nitrophenoxide 4- & 50.0 \\
\hline Sodium nitrosophenoxide 4- & 90.0 \\
\hline Sodium dinitrophenoxide 2,4- & 410.0 \\
\hline Sodium penylphenoxide 2 - & 0.6 \\
\hline Sodium penylphenoxide 4- & 1.0 \\
\hline Sodium phenylazophenoxide 4- & 6.0 \\
\hline Glycerine & 3.2 \\
\hline Acetonitrile & 5.0 \\
\hline Acetone & 2.5 \\
\hline methylene chloride & 2.4 \\
\hline Hydrogen peroxide & 0.8 \\
\hline Surfyol 420 & 25.0 \\
\hline Quinone & 1.0 \\
\hline Biphenyl & 3.0 \\
\hline Terphenyl-o & 1.0 \\
\hline Terphenyl-m & 1.0 \\
\hline Terphenyl-p & 1.0 \\
\hline Diphenylamine & 3.0 \\
\hline Triphenylamine & 1.0 as diphenylamine \\
\hline Nitrodiphenylamine & 1.0 as nitrophenylamine \\
\hline Phenylformamide & 5.0 \\
\hline Diphenylformamide & 1.0 \\
\hline Carbazole & 1.0 \\
\hline
\end{tabular}




\subsection{Method}

The uptake of cesium with CST, or mercury onto Duolite GT-73 or SAMMS, was studied by a batch technique. The batch distribution coefficient $\left(\mathrm{K}_{d}, \mathrm{~mL} / \mathrm{g}\right)$ is an equilibrium measure of the overall ability of a solid phase ion exchange material to remove ions of interest from solution. It represents the theoretical volume of solution that can be processed per given mass of the ion exchanger under equilibrium conditions (2).

For this study a known quantity of the resin (approximately 0.1 grams) was placed in contact with $25 \mathrm{ml}$ of the simulant in a $50-\mathrm{ml}$ polyethylene bottle. All samples were prepared in either duplicate or triplicate. The polyethylene bottles were placed in an orbital shaker and the mixture agitated for 24 hours at $26 \pm 2{ }^{\circ} \mathrm{C}$. After this contact time, the used resin was separated from the solution by filtering through a 0.2 -micron nylon filter. The decanted portion, without resin, was submitted for metal concentration analysis. The $\mathrm{K}_{\mathrm{d}}$ values were calculated using Equation (1),

$$
\mathrm{K}_{\mathrm{d}}=\left(\left(\mathrm{C}_{\mathrm{i}}-\mathrm{C}_{\mathrm{f}}\right) / \mathrm{C}_{\mathrm{f}}\right) *(\mathrm{v} / \mathrm{m} * \mathrm{~F})
$$

Where, $C_{i}$ is the initial concentration of the metal ion of interest, $C_{f}$ is the final metal concentration after contact, $\mathrm{v}$ is the volume of simulant used, $\mathrm{m}$ is the sorbent exchanger mass and $\mathrm{F}$ is the F-factor (ratio by weight of dry sorbent to wet sorbent). In the above equation, it is assumed that the mass of dry ion exchange sorbent is approximately equal to that of wet ion exchange sorbent used $(\mathrm{F} \approx 1.0)$. Note that the amount of metal on the resin following sorption is calculated by difference in the solution $\left(C_{i}-C_{f}\right)$.

For radioactive samples, or simulants spiked with radionuclides, $\mathrm{K}_{\mathrm{d}}$ values were determined using equation (2),

$$
\mathrm{K}_{\mathrm{d}}=\left(\left(\mathrm{A}_{\mathrm{i}}-\mathrm{A}_{\mathrm{f}}\right) / \mathrm{A}_{\mathrm{f}}\right) * \mathrm{v} / \mathrm{m}
$$

Where $A_{i}$ and $A_{f}$ are the activities of the radionuclide in solution at the beginning and at the end of sorption, respectively, $\mathrm{v}$ is the volume in $\mathrm{ml}$ of the solution used for equilibration and $\mathrm{m}$ is the weight of the adsorbent in grams.

\section{RESULTS AND DISCUSSION}

\subsection{Cesium Uptake with CST in an Inorganic DWPF Simulant}

In the initial characterization of cesium uptake with CST a $5.6 \mathrm{M} \mathrm{Na}^{+}$simulant (upper limit simulant) without organic additives was used. The simulant inorganic ion composition and concentrations are shown in Table 2 above. In this initial batch study, three simulant samples with an average Cs-133 concentration of $3.86 \pm 0.21 \mathrm{mg} / \mathrm{L}$ were used. The average $\mathrm{K}_{d}$ obtained was $1509 \pm 95 \mathrm{ml} / \mathrm{g}$. This $\mathrm{K}_{d}$ value for cesium uptake agrees with earlier results obtained by McCabe (3). The $\mathrm{K}_{\mathrm{d}}$ values obtained and total 
potassium ion concentration in each sample is summarized in Table 8. Note that potassium concentration is listed because it can act as a competing ion for cesium uptake with CST.

Table 8. $\mathrm{K}_{\mathrm{d}}$ values for cesium uptake with CST ( $\left.5.6 \mathrm{M} \mathrm{Na}^{+}\right)$.

\begin{tabular}{|c|c|c|c|}
\hline Run \# & {$[\mathrm{Cs}-133] \mathrm{mg} / \mathrm{L}$} & {$\left[\mathrm{K}^{+}\right] \mathrm{mg} / \mathrm{L}$} & $\mathrm{Cs}-133 \mathrm{~K}_{\mathrm{d}}$ \\
\hline 1 & 3.66 & 464.095 & 1601.78 \\
\hline 2 & 3.84 & 463.085 & 1514.97 \\
\hline 3 & 4.08 & 517.120 & 1411.15 \\
\hline Average & $3.86 \pm 0.21$ & & $1509 \pm 95$ \\
\hline
\end{tabular}

\subsection{Cesium Uptake with CST in Organic and Inorganic DWPF Simulants}

DWPF simulants were prepared with both inorganic and organic components based on Types A and B simulants (i.e., high and average sodium/organic/inorganic DWPF recycle simulants). The $\mathrm{pH}$ of these simulant solutions was 13.3. Since the effectiveness of cesium uptake by CST was also to be evaluated at other $\mathrm{pH}$ conditions $(13,7$ and 2$)$, solutions of the original high and average simulants were adjusted with nitric acid (1.0 $\mathrm{M}$ ) to the desired $\mathrm{pH}$ levels. In all, six sample types of simulant solutions were prepared for $\mathrm{K}_{\mathrm{d}}$ measurement; High RCT (DWPF Type A simulant) at $\mathrm{pH}$ 's of 13, 7 and 2, and Average RCT (DWPF Type B simulant) at $\mathrm{pH}$ 's of 13, 7 and 2. Corresponding blanks without CST were also prepared. Cesium-133 concentration in each sample was approximately $32 \mathrm{mg} /$. These particular sets of samples were prepared in triplicate. $\mathrm{K}_{\mathrm{d}}$ measurements were made using the procedure described in the method section above.

For comparison, SMECT sample from TNX operations, which already contained mercury and DWPF organic compounds, was also used in determining batch $\mathrm{K}_{\mathrm{d}}$ values for CST. With this TNX SMECT sample, an equivalent amount of cesium nitrate $(0.0118 \mathrm{~g})$ was introduced into a $250-\mathrm{ml}$ sample to bring its cesium concentration to $32 \mathrm{mg} / \mathrm{L}$. The $\mathrm{pH}$ of three 25-ml representative samples from this batch of modified SMECT samples was adjusted with sodium hydroxide, respectively, to $\mathrm{pH}$ values of 2, 7, and 13. Each of the 25-ml samples, with different $\mathrm{pH}$ values $(2,7$ and 13$)$, was treated with $0.10 \mathrm{~g}$ CST as described previously.

Residual cesium analysis of all the above samples, wr.ich were contacted with CST, were delayed for about 4 months due to funding problems. After this delay a selected number of the samples were analyzed, yielding an average $K_{d}$ value of $2400 \pm 50 \mathrm{ml} / \mathrm{g}$. This value is significantly different from an average batch $K_{d}$ value of $1500 \pm 95 \mathrm{ml} / \mathrm{g}$ obtained for the baseline simulant without organic components (Table 2). Here one expects a decrease in $\mathrm{K}_{d}$ values with organic components in the simulant. The increase in $\mathrm{K}_{\mathrm{d}}$ value was attributed to the plating out of cesium with organic films onto the sides of the sample vials or containers during the four months delay. 


\subsection{SRS Tank 22 Measurements}

Tank 22 is currently the intermediate storage destination for DWPF recycle and other Tank Farm dilute waste solutions. The chemical makeup of Tank 22 waste stream was reviewed with the plant customer to tailor some of the $K_{d}$ experiments towards cesium removal from Tank 22. The simulant composition for Tank 22 was determined to be similar to the existing DWPF average simulant make up with only 0.5 molar sodium ion concentration and an average organic content (Type $C$ simulant). A summary of the organic and inorganic concentrations is presented in Table 7.

This phase of the CST work was also designed to address, among other things, questions dealing with the variation of $\mathrm{K}_{\mathrm{d}}$ with cesium concentration and the ionic strength of the recycle waste stream.

\subsection{Variation of Batch Distribution Coefficient With Cesium Concentration}

The effect of initial cesium concentration on batch $\mathrm{K}_{\mathrm{d}}$ measurements for CST were evaluated using Tank 22 simulant and cesium concentrations ranging from 5.87 to 61.30 $\mathrm{mg} / \mathrm{L}$. The Tank 22 simulant was based on composition shown in Table 7 and had solution $\mathrm{pH}$ of 13 . Batch $\mathrm{K}_{\mathrm{d}}$ measurements were made using the procedure summarized in the method section. Under this ionic strength condition, increase in $K_{d}$ with increase in cesium concentration leveled off after about $35 \mathrm{mg} / \mathrm{l}$ of cesium. Results are summarized in Table 9 and Figure 1.

Table 9. $K_{d}$ Variation with Initial Cesium Concentration.

\begin{tabular}{|c|c|}
\hline$[\mathrm{Cs}-133] \mathrm{mg} / \mathrm{L}$ & $\mathbf{K}_{\mathrm{d}}(\mathrm{m} / \mathrm{g})$ \\
\hline & \\
\hline 5.87 & 31112 \\
\hline 10.98 & 32467 \\
\hline 16.90 & 34958 \\
\hline 26.04 & 38967 \\
\hline 30.01 & 38583 \\
\hline 40.27 & 43923 \\
\hline 52.64 & 42577 \\
\hline 61.30 & 40789 \\
\hline
\end{tabular}




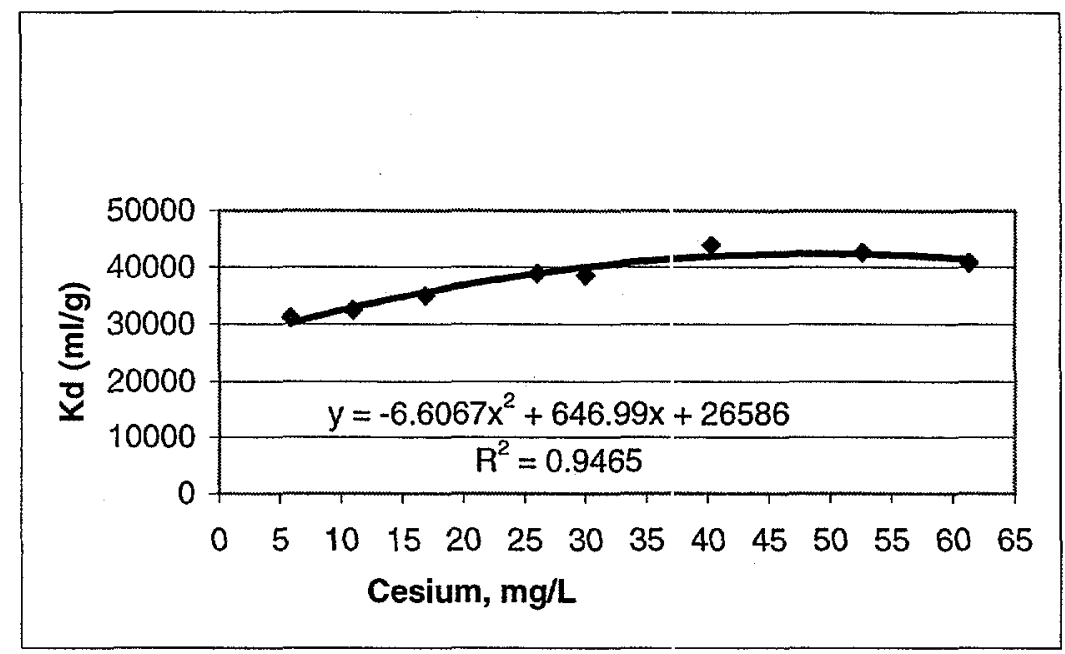

\section{Figure 1. Variation of $\mathbf{K}_{\mathbf{d}}$ With Initial Cesium Concentration.}

Based on equation (1) above, the batch distribution coefficient is expected to be linear with respect to the decontamination factor, $\mathrm{C}_{\mathrm{i}} / \mathrm{C}_{\mathrm{f}}$, [within the linear response region of Figure 1 above (i.e., below $30 \mathrm{mg} / \mathrm{L}$ )]. A summary of the basic equations gives:

$$
\begin{aligned}
& \mathrm{K}_{\mathrm{d}}=\left(\left(\mathrm{C}_{\mathrm{i}}-\mathrm{C}_{\mathrm{f}}\right) / \mathrm{C}_{\mathrm{f}}\right)^{*}(\mathrm{v} / \mathrm{m}) . \\
& \text { If } \beta=\mathrm{v} / \mathrm{m} \text {, then } \\
& \mathrm{K}_{\mathrm{d}}=\beta(\mathrm{Ci} / \mathrm{Cf}-1)=\beta \mathrm{Ci} / \mathrm{Cf}-\beta
\end{aligned}
$$

To validate equation (3) several of the $K_{d}$ measurements in the cesium concentration region of interest were plotted with the correspondirig decontamination factor. Using a test solution volume of $25 \mathrm{ml}$ and CST weight of $0.1 \mathrm{~g}$ equation (3) becomes:

$$
\mathrm{K}_{\mathrm{d}}=250 \mathrm{Ci} / \mathrm{C}_{\mathrm{f}}-250 \text {. }
$$

Experimentally, per equation (4), a plot of $\mathrm{K}_{\mathrm{d}}$ versus $\mathrm{Ci} / \mathrm{C}_{\mathrm{f}}$ (decontamination factor) should give a straight line with a slope equal to 250 and intercept of -250 .

The experimental results confirming equation (3) withı Tank 22 simulant are summarized in Table 10 and Figure 2. The slope and intercept from the experimental data, 250 and 250.81 respectively, are in excellent agreement with the theoretical values of equation 4. 
Table 10. $K_{d}$ variation with decontamination factor.

\begin{tabular}{|c|c|c|c|}
\hline $\mathrm{C}_{\mathrm{i}, \mathrm{mg} / \mathrm{L}}$ & $\mathrm{C}_{\mathrm{f}, \mathrm{mg} / \mathrm{L}}$ & $\mathrm{K}_{\mathrm{d}, \mathrm{ml} / \mathrm{g}}$ & {$\left[\mathrm{C}_{\mathrm{i}}\right] /\left[\mathrm{C}_{\mathrm{f}}\right]$} \\
\hline & & & \\
\hline 5.871 & 0.047 & 31112 & 125.45 \\
\hline 10.980 & 0.084 & 32467 & 130.87 \\
\hline 16.900 & 0.120 & 34958 & 140.83 \\
\hline 26.040 & 0.166 & 38967 & 156.87 \\
\hline
\end{tabular}

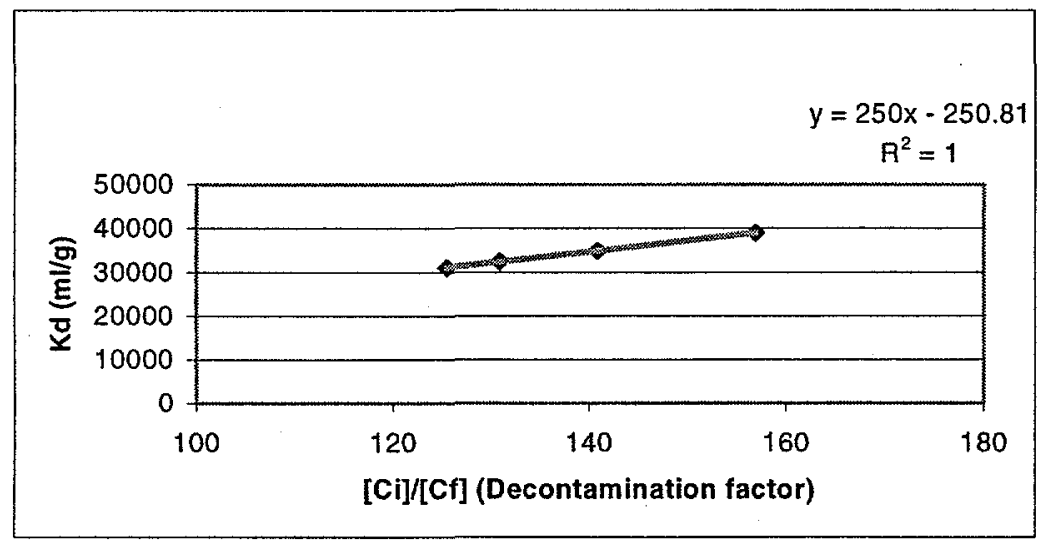

Figure 2. Linear Response of $K_{d}$ with Cesium Decontamination Factor.

\subsection{Variation of Batch Distribution Coefficient With Ionic Strength.}

The effect of ionic strength on batch $\mathrm{K}_{\mathrm{d}}$ measurements for CST were evaluated using Tank 22 simulant at ionic strengths of 0.5, 1.4 and 5.4 molar sodium. Each solution contained an average of $0.26 \pm 0.15$ moles of cesium per liter. The $K_{d}$ values obtained are summarized in Table 11 and Figure 3 . The data clearly shows that $\mathrm{K}_{\mathbf{d}}$ increases with a decrease in the ionic strength of the test solution.

Table 11. $K_{d}$ Variation with Ionic Strength.

\begin{tabular}{|c|c|c|c|}
\hline$[\mathrm{Cs}] \mathbf{i}$ (moles) & {$[\mathbf{N a}+]$, moles } & $\mathbf{K d}(\mathrm{ml} / \mathrm{g})$ & $\begin{array}{c}\left.\left(\left[\mathrm{Na}^{+}\right] / \mathrm{Cs}\right] \mathrm{i}\right) \\
\text { mole/mole }\end{array}$ \\
\hline 0.24925 & 0.5 & 37400 & 2.0060 \\
\hline 0.26060 & 1.4 & 8000 & 5.3722 \\
\hline 0.28045 & 5.4 & 1300 & 19.2547 \\
\hline
\end{tabular}




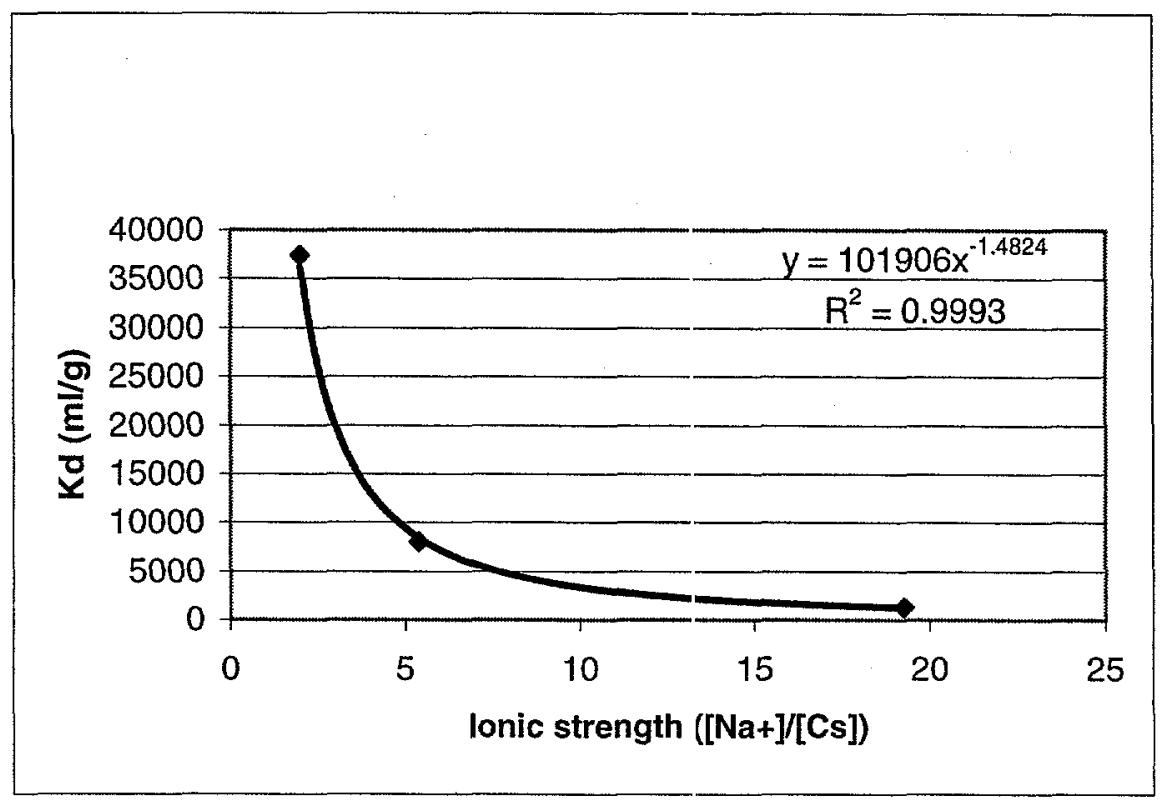

Figure 3. Variation of $K_{d}$ with Ionic Strength.

The region of interest for cesium-133 removal from DWPF recycle (less than $1 \mathrm{mg} / \mathrm{L}$ cesium or 7.519 E-6 moles of cesium-133/Liter) cannot be fully characterized with cesium-133 simulant. This problem is due, in part to the question of minimum detection limit for cold cesium (Cs-133) using standard ICP-IMS analytical techniques. To get around this problem Tank 22 simulant $\left(0.5 \mathrm{M} \mathrm{Na}^{+}\right)$was spiked with cesium-137 and the $\mathrm{K}_{\mathrm{d}}$ determined by quantifying cesium-137 using gamma counting and equation (2) above.

\subsection{Experiments With Cesium-137 Spiked Tank-22 Simulant}

Four samples (25-mL solutions of Tank 22 simulant each) were spiked with $0.5 \mathrm{~mL} \mathrm{Cs-}$ 137 tracer (concentration of $20.8 \mathrm{ppb} \mathrm{Cs}-137$ or $9.2 \mathrm{E} 05 \mathrm{~d} / \mathrm{min}-\mathrm{mL}$ ). Cesium-137 concentration in grams was based on $87 \mathrm{~g} \mathrm{Cs}-137 / 1.23 \mathrm{~J} 12 \mathrm{~d} / \mathrm{min}-\mathrm{ml}$. The average amount of cesium-137 in each sample was $6.584 \mathrm{E}-07 \mathrm{~g}$ or $4.95 \mathrm{E}-09$ moles. A volume of $2.5 \mathrm{ml}$ from each sample was used for gamma counting $(10,000-\mathrm{sec}$ count) after overnight contact with approximately $0.1 \mathrm{~g}$ of CST.

The results are summarized in Table 12 , which shows an average $\mathrm{K}_{\mathrm{d}}$ value of 74,500 $\mathrm{ml} / \mathrm{g}$. The final cesium concentration, after uptake with CST, may not differ greatly from background readings for cesium-137 in the area where the analysis was carried out. Consequently, the fourth sample was re-counted for a longer period of time $(50,000-\mathrm{sec}$. count) resulting in a $\mathrm{K}_{\mathrm{d}}$ of $327,425 \mathrm{ml} / \mathrm{g}$ versus $77,752 \mathrm{ml} / \mathrm{g}$ for a 10,000 -second count. 
Table 12. Data Summary for Tank-22 Simulants Spiked with Cesium-137.

\begin{tabular}{|c|c|c|c|}
\hline Run \# & $\begin{array}{c}\text { Initial Cs-137 activity, } \\
\text { Gamma count; d/min-ml }\end{array}$ & $\begin{array}{c}\text { Final Cs-137 activity } \\
\mathbf{d} / \mathbf{m i n}-\mathbf{m l}\end{array}$ & $\mathbf{K d ~ ( m l / g )}$ \\
\hline 1 & $1.71 \mathrm{E} 04$ & & 60 \\
\hline 2 & $1.66 \mathrm{E} 04$ & 47 & 61,207 \\
\hline 3 & $1.68 \mathrm{E} 04$ & 53 & 82,288 \\
\hline 4 & $1.70 \mathrm{E} 04$ & 50 & 76,694 \\
\hline Average & $1.69 \mathrm{E} 04 \pm 0.02 \mathrm{E} 04$ & $52.5 \pm 3.8$ & 77,752 \\
\hline
\end{tabular}

Actual Tank 22 waste was recently secured and evaluated for cesium- 137 removal with CST (3). The average $K_{d}$ value reported was $14,850 \pm 2,380 \mathrm{ml} / \mathrm{g}$. The $K_{d}$ values in reference 3 are significantly lower than that reported here. This is probably because of the effect of low sodium and cesium- 137 concentration in the Cs-137 spiked simulant.

\subsection{Mercury Removal From DWPF Simulant}

The uptake of mercury from DWPF simulant using the Self-Assembled Monolayers on Mesoporous Support (SAMMS) material from PNNL (4) was evaluated with the Type A DWPF simulant $\left(\left[\mathrm{Na}^{+}\right]\right.$of $5.4 \mathrm{M}$ and $\mathrm{pH}$ of 13$)$ containing mercury. The SAMMS material was expected to outperform standard GT-73 ion exchange material for mercury removal from DWPF waste stream.

The contact results of this SAMMS and GT-73 ion exchange material with DWPF simulant containing both mercury and organic compound (Table 13 below) shows that the SAMMS material, in its current configuration, has no affinity for DWPF waste stream mercury $\left(K_{d}=0.0\right)$. Even ordinary sulfur powder showed a better affinity for mercury than SAMMS at a solution $\mathrm{pH}$ of 13 . The $\mathrm{K}_{\mathrm{d}}$ value for mercury removal from DWPF simulant using GT-73 averaged about $8,900 \mathrm{ml} / \mathrm{g}$. The SAMMS material does, however, show $K_{d}$ values less than $600 \mathrm{ml} / \mathrm{g}$ when there are no organic compounds in the simulant waste stream.

The mercury removal evaluations with SAMMS and Duolite GT-73 resins were repeated with Tank 22 simulant. This time, the $\mathrm{pH}$ of the simulant solution was adjusted to 2, 7 and 13 before the batch $K_{d}$ work with the resins. Concentrated nitric acid and $0.10 \mathrm{M}$ solution of sodium hydroxide were used for $\mathrm{pH}$ adjustments. The new $\mathrm{K}_{\mathbf{d}}$ values are summarized in Table 14 and plotted in Figures 4 and 5. 
Table 13. Kd Values for SAMMS and Duolite GT-73 Resin for Mercury Removal from Type A DWPF Simulant.

\begin{tabular}{|c|c|c|c|c|}
\hline Sample ID & $\mathbf{C}_{\mathbf{i}}[\mathbf{H g}] \mathbf{p p m}$ & $\mathbf{C}_{\mathrm{f}}[\mathbf{H g}] \mathbf{p p r n}$ & $\mathbf{K d s}(\mathbf{m} / \mathrm{g})$ & Average $\mathbf{k}_{\mathbf{i}}$ \\
\hline Initial [Hg] & & & & \\
\hline & 38.739 & & & \\
\hline GT-73 run 1 & 38.739 & 1.0875 & 8646 & 8918 \\
\hline GT-73 run 2 & 38.739 & 1.0250 & 9189 & \\
\hline & & & & \\
\hline SAMMS run 1 & 38.739 & 39.9 & 0.0 & 0.0 \\
\hline SAMMS run 2 & 38.739 & 39.0 & 0.0 & \\
\hline SAMMS run 3 & 117.08 & 34.67 & 594.2 & 594.2 \\
\hline & & & & \\
\hline Sulfur run 1 & 38.739 & 5.625 & 1470 & 1544 \\
\hline Sulfur run 2 & 38.739 & 5.1750 & 1619 & \\
\hline
\end{tabular}

Table 14. $K_{d}$ Values for SAMMS and Duolite GT-'/3 Resin for Mercury Removal from Tank-22 Simulant.

\begin{tabular}{|c|c|c|c|}
\hline \multicolumn{2}{|c|}{ Duolite GT-73 Resin } & \multicolumn{2}{c|}{ SAMMS Resin } \\
\hline $\mathrm{pH}$ & $\mathrm{Kd}(\mathrm{ml} / \mathrm{g})$ & $\mathrm{pH}$ & $\mathrm{Kd}(\mathrm{ml} / \mathrm{g})$ \\
\hline 2 & 119 & 2 & 0 \\
\hline 7 & 1213 & 7 & 233,522 \\
\hline 13 & 9179 & 13 & 0 \\
\hline & & & \\
\hline
\end{tabular}

The SAMMS material showed a significant affinity for the uptake of mercury at neutral $\mathrm{pH}$ of 7 . The batch distribution coefficient for mercury removal at this neutral $\mathrm{pH}$ was $233500 \mathrm{ml} / \mathrm{g}$. The SAMMS did not remove mercury from simulants with lower or higher $\mathrm{pH}$ values (Figure 4). The GT-73 performed as expected. Its affinity for mercury increased with increase in $\mathrm{pH}$ (Figure 5).

\subsection{Mercury Removal From Tank 22 Sample With GT-73.Resin}

McCabe (3) documents the collection and characterization of actual Tank 22 sample used in this part of the mercury removal study. The mercury removal $K_{d}$ data obtained by McCabe was based on filtered Tank 22 samples. The average $\mathrm{K}_{\mathrm{d}}$ reported with GT-73 resin $\left(\mathrm{Na}^{+}\right.$form) was $39,885 \pm 3000 \mathrm{ml} / \mathrm{g}$. The initial mercury concentration in Tank 22 sample was $10.95 \mathrm{mg} / \mathrm{L}$ and the ending mercury concentration was $0.070 \pm 0.006 \mathrm{mg} / \mathrm{L}$. 20-ml sample volumes were used with $0.075 \mathrm{~g}$ of GT-73 in $\mathrm{K}_{d}$ determinations. 


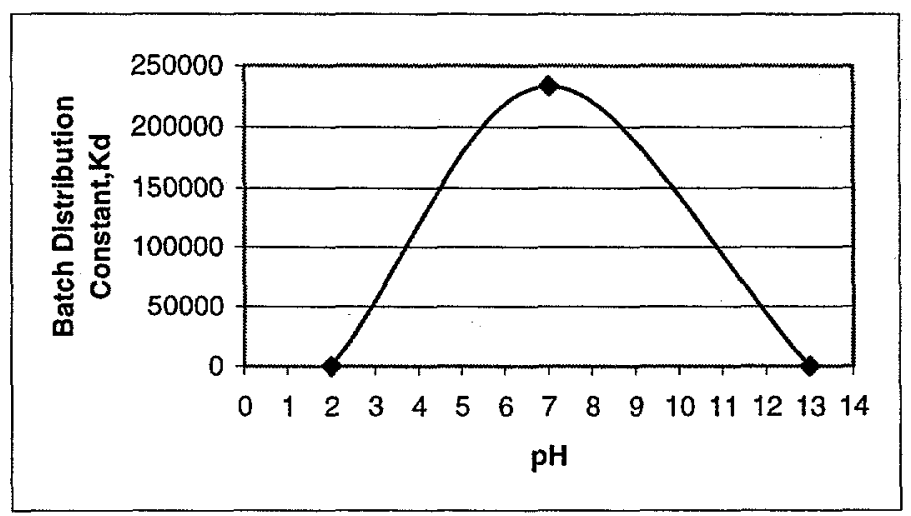

Figure 4. Estimated $\mathrm{K}_{\mathrm{d}}$ Variation Profile with $\mathrm{pH}$ for Mercury Removal with SAMMS.

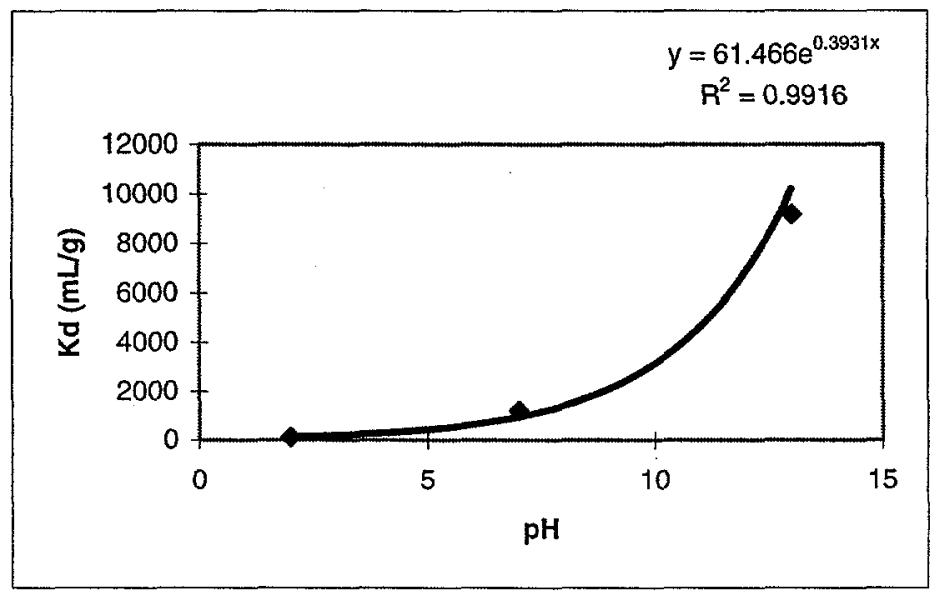

Figure 5 Variation of Kd with pH for Mercury Removal with Duolite GT-73.

\section{CONCLUSIONS}

The results of this evaluation of the performance of CST in the uptake of cesium with simulants and actual DWPF recycle samples (Tank 22) indicate that, in practice, this inorganic ion-exchange material can be used to remove radioactive cesium from the DWPF recycle. Even in high ionic strength environments the CST material has affinity for cesium. Characterization of the effect of organic components on the efficiency of cesium or mercury removal from DWPF simulants using, respectively, CST and SAMMS or Duolite ${ }^{\circledR}$ GT-73 was aborted due to interruption in the analysis of samples due to a funding shortfall. Based on the data obtained the following conclusions are made: 
- Batch distribution coefficient $\left(\mathrm{K}_{\mathrm{d}}\right)$ for cesium removal with alkaline DWPF simulant solution increases with decreasing ionic strength.

- The batch distribution coefficient for alkaline DWPF simulant showed a linear variation with initial cesium-133 concentration up to approximately $35 \mathrm{mg} / \mathrm{L}$.

- The $\mathrm{K}_{\mathrm{d}}$ value for cesium uptake from DWPF hight ionic sodium salt solution (5.4 M $\left.\left[\mathrm{Na}^{+}\right]\right)$is $1500 \mathrm{ml} / \mathrm{g}$. For low sodium salt solution, $\left(0.5 \mathrm{M}\left[\mathrm{Na}^{+}\right]\right)$, the $\mathrm{K}_{d}$ value obtained is $37,000 \mathrm{ml} / \mathrm{g}$.

- Radioactive cesium spiked simulant $\left(0.5 \mathrm{M}\left[\mathrm{Na}^{+}\right]\right)$, with cesium- 137 activity of 1.69E04 d/min-ml, showed a CST cesium- 137 uptake $\mathrm{K}_{\mathrm{d}}$ value of $74,500 \mathrm{ml} / \mathrm{g}$.

- Self-Assembled Monolayers on Mesoporous Support from PNNL had no affinity for DWPF simulant mercury. However, with the $\mathrm{pH}$ of the simulant adjusted to a value of 7 (neutral $\mathrm{pH}$ condition), SAMMS material showed its highest affinity for DWPF mercury $\left(\mathrm{k}_{\mathrm{d}}\right.$ of $\left.233,000 \mathrm{ml} / \mathrm{g}\right)$.

- The $K_{d}$ for the uptake of mercury from DWPF simulant with conventional Duolite ${ }^{\circledR}$ GT-73 resin was found to increase with increasing $\mathrm{pH}$ of the simulant solution.

- GT-73 ion-exchange affinity for mercury from actual Tank $22 \mathrm{H}$ sample was quite good. The average determined $\mathrm{K}_{\mathrm{d}}$ value was $39,700 \mathrm{ml} / \mathrm{g}$.

Additional work that needs to be carried out before implementing this program includes the following:

- Column performance evaluations with CST in DWPF simulant and actual waste solutions.

- Determination of batch $\mathrm{K}_{\mathrm{d}}$ values at different DWPF simulant $\mathrm{pH}$ conditions.

- Evaluation of the affinity of CST for other transuranic elements, and

- Evaluation of strontium-90 uptake with Sodium Titanate (ST) and crossflow filtration characterizations with ST.

- Evaluation of the effect of organic loading on the efficiency of CST in removing cesium, and GT-73 and SAMMS in removing mercury.

\section{QUALITY ASSURANCE}

All experimental work reported in this document was obtained in accordance with the requirements and controls established in the Savannah River Technology Center Conduct of Research and Development manual (WSRC-IM-97.00024). Experimental methods and data are recorded in laboratory notebook, WSRC-NB-96-655. 


\section{Acknowledgements}

Dennis Fennelly of UOP and Dr. Feng of PNNL, provided the crystalline silicotitanate (CST) and the Self-Assembled Monolayers on Mesoporous Support (SAMMS), respectively. The Department of Energy, Office of Science and Technology, through the Efficient Separations and Processing Crosscutting Program, funded this work.

\section{REFERENCES}

(1) Klavetter , E. A, Brown , N. NE., Trudell, D. E., Anthony, R. G., Gu, D, and Thibaud-Erkey, C, "Ion-Exchange Performance of Crystalline Silicotitanate for Cesium Removal from Hanford Tank Waste Simulants," Waste Management 04, p. 709, Tucson, AZ.

(2) G. N. Brown, L A. Bray and R. J. Elovich, "Evaluation and Comparison of Superlig® 644, Resorcinol Formaldehyde and CS-100 Ion Exchange Materials for the Removal of Cesium from Simulated Alkaline Supernate". PNL-10486, March 1995.

(3) D. J. McCabe, L. N. Oji, "Distribution Coefficients for Crystalline Silicotitanate with Tank-22H (U)," WSRC-TR-98-00197, Rev. 0.0, June 16, 1998.

(4) X. Feng, J. Liu, G. E. Fryxell, M. Gong, L. Q. Wang, X. Chen, D. E. Kurath, C. S. Ghormley, K. T. Klasson, and K. M. Kemner, Self-Assembled Mercaptan on Mesoporous Silica (SAMMS) Technology for Mercury Removal and Stabilization, PNNL-11691, Pacific Northwest National Laboratory, Richland, WA (1997). 